\title{
Pathological Lesions in the Right and Left Porcine Lung: Evaluation of an Alternative Method for Scoring Pneumonic Lesions based on Right Lung Examination
}

\author{
By J. Mousing and G. Christensen
}

The Federation of Danish Pig Producers and Slaughterhouses, Veterinary Division, Copenhagen, Denmark.

\begin{abstract}
Mousing, J. and G. Christensen: Pathological lesions in the right and left porcine lung: Evaluation of an alternative method for scoring pneumonic lesions based on right lung examination. Acta vet. scand. 1993, 34, 151-158. - Plucks from 2,372 sows, gilts and slaughterswine (originating from 3 independent sources) were evaluated for presence and severeness of 6 different pathological entities. Results were calculated for each of the lungs separately and compared to the combined findings of both lungs. Both qualitatively (comparing relative test sensitivities) and quantitatively (comparing lung scores), the right lung results were more optimal than the left lung outcomes and relatively consistent among the 3 data sets. The over-all right lung relative sensitivities for the detection of catarrhal pneumonia or chronic pleuritis were $81.3 \%$ and $72.0 \%$, respectively. The over-all differences in the right minus left lung scores for the 2 lesions were $+13.0 \%$ and $+9.0 \%$, respectively. The necessary sample size of right lungs to detect at least 1 lung with catarrhal pneumonia or chronic pleuritis is presented along with a method for calculating confidence intervals.
\end{abstract}

swine respiratory disease; lung score; diagnostic test.

\begin{abstract}
Introduction
Scoring systems: Applications and practical problems

Evaluation of pathological pneumonic lesions in pigs has been used extensively for herd health monitoring as well as in research on respiratory diseases of pigs (Morrision et al. 1985). Frequently, the objective of such examinations is to evaluate the level of chronic catarrhal or complicated catarrhal pneumonia, but several other lesions may be examined as well (Christensen \& Mousing 1992). Scoring the extent of lesions is typically performed on the entire thoracic organs (plucks) based on slaughterhouse material. When examining plucks from a batch of 30-50 slaugh-
\end{abstract}

ter pigs, we have experienced considerable practical problems. The plucks need to be removed from the slaughterline, which interferes with the routine slaughterhouse procedures in several ways. Most importantly, it stops the flow of plucks at the slaughterline in the time interval when the carcasses of interest are processed, and over-flows the line when the pathological examination is finished. Also, removal of the entire plucks from the slaughterline is unacceptable in many instances, leaving the investigator with only little time to score the lungs.

An alternative procedure that does not interfere with the slaughterhouse procedure and ensures sufficient time for examination would 


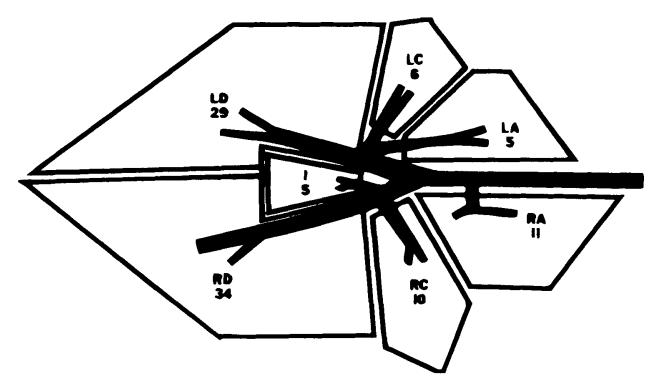

Figure 1. Schematic drawing of the porcine lung.

LD : Left diaphragmatic lobe

LC : Left cardiac lobe

LA : Left apical lobe

RD: Right diaphragmatic lobe

RC: Right cardiac lobe

RA: Right apical lobe

I : Intermediate lobe

The relative weight of the different lobes in percent of the total weight of both lungs are indicated (as determined by Christensen 1990).

thus be advantageous. An attractive method could be to slice off 1 of the lung halves from the plucks of interest, and to examine this material at a more convenient place and time.

The aim of this paper is to evaluate the diagnostic merits of separate pathological examinations of the right and left lung. A study was performed to estimate the relative sensitivities of examinations of the right and left lung as well as the association found between the severeness of the lesions (lung scores) for each of the lungs compared to the combined findings in the plucks. Also, some statistical aspects of using the right lung test are discussed. Two questions were stated: First, how many pigs should one examine to be certain (at a given confidence level), to detect at least 1 lung with lesions, given different in-herd prevalences. Second, given an apparent prevalence determined by the right lung test result, which confidence interval can be established for this result.
Anatomic differences between the left and right porcine lung

For anatomical reasons it may be expected that the relative sensitivity of examining either left or right lung will differ. Most importantly, the right lung contributes more than half of the total lung weight (Fig. 1). In 3 different studies, the right lung constituted 55$60 \%$ of the weight of both lungs (Morrison et al. 1985, Heilmann et al. 1988, Christensen 1990).

Also the tubular tract system differs between the right and the left lung. The trachea divides posteriorily into 2 principal bronchi, 1 for the left and 1 for the right lung. However, a special stembronchus arises directly from the trachea for the apical lobe of the right lung. The intermediate lobe of the right lung receives a stembranch from the right principal bronchus (Fig. 1).

\section{Materials and methods}

A total of 2,372 plucks were examined. The plucks originated from 3 independent data sets: Data set 1 constituted 1,767 randomly selected plucks from sows and gilts that were (routinely) slaughtered at a Danish abattoir. Sets 2 and 3 comprised 304 and 301 plucks, respectively, that originated from pigs from 2 conventional farrow-to-finish herds, described elsewhere (Vraa-Andersen 1991, Paisley 1991).

All plucks were evaluated by a method described by Christensen (1991). The following lesions were recorded: Uncomplicated catarrhal pneumonia, chronic pleuritis, interlobular scar retractions, acute pleuropneumonia, complicated catarrhal bronchopneumonia and chronic pleuropneumonia. A detailed description of the different pathological entities is given by Christensen \& Mousing (1992). Whenever lesions occurred it was given a score defined as the percentage of the dorso- 
lateral lung surface (chronic pleuritis), the percentage of the lung weight (the different types of pneumonia), or a score for interlobular scar retractions (from 0 to 3 by 0.5 ). All plucks were scored visually by the same veterinarian.

\section{Statistical analysis}

For an analysis of the qualitative merits of examining either left or right lung, the relative sensitivities for the specific pathological lesions (defined above) were calculated for each of the lungs (Martin et al. 1987). For a given lesion and lung (left or right), this was defined as the number of lungs with lesions relative to the number of plucks with lesions. The right lung results (among plucks with lesions) were compared between the 3 data sets using a standard $\mathrm{Chi}^{2}$ test. The over-all lesion specific sensitivities for right and left lungs were compared using a McNemar's test for paired proportions (Armitage \& Berry 1987). Among left and right lungs with pathological findings, the relative difference in lung scores, defined as the right lung score minus the left lung score in percent of the score of the plucks was computed. This calculation was performed for plucks in which at least 1 lung presented lesions, and for plucks in which both lungs were affected. The relative score difference was tested for the hypothesis that this was equal to zero (using a t-test). This material was further analyzed for herd effects using a one-way analysis of variance, and by calculation of the correlation coefficients between the relative score difference and the score of the plucks (Armitage \& Berry 1987). The statistical software SASR was used in the data analysis (SAS Institute Inc 1988).

\section{Statistical aspects of a right lung test}

The sample size (m) necessary to detect at least 1 right lung with uncomplicated catar- rhal pneumonia or chronic pleuritis (at different prevalences and with $95 \%$ certainty) was estimated using the following equation (Martin et al. 1987):

$$
m=\left[1-\left(1-0.95^{\frac{1}{D}}\right)\right]\left(N-\frac{D-1}{2}\right)
$$

where $\mathrm{N}$ is the size of the herd and D is the expected number of affected right lungs (i.e. the integer value of: $\mathbf{N}$ times the prevalence of lesions in the plucks times the test sensitivity). If, in a sample of $\mathrm{m}$ right lungs, an apparent prevalence (denoted by $b$ ) of right lungs is found positive for, say, catarrhal pneumonia, what can be said about the true in-herd prevalence ? Firstly, one should consider the sensitivity (s) of the test for obtaining a point estimate. Then the point estimate for the true prevalence ( $p$ ) is b/s. To obtain a $95 \%$ confidence interval around this point estimate one may estimate this by the binomial approximation (including a correction factor for the size of the herd, N, Levy \& Lemeshow 1980):

$$
\frac{b \pm 1.96\left[\frac{b(1-b)}{m-1}\right]^{1 / 2}\left[\frac{N-m}{N}\right]^{1 / 2}}{s}
$$

\section{Results}

The over-all results are listed in Tables 1 and 2 , and the relative sensitivities of left and right lung examinations are shown in Table 3.

Table 4 illustrates the relative difference in lung score (as defined above), restricted to plucks in which lesions were detected in either left or right lung, or in both lungs. The differences were tested for the hypothesis of being equal to zero, and p-values are indicated in the table. An analysis of variance of these data revealed that the results for catarrhal pneumonia and interlobular scar retraction differed between the 3 data sets $(p=0.013$ and 
Table 1. Over-all results of the study. The number of right lungs, left lungs and both lungs by data set and pathological lesion.

\begin{tabular}{|c|c|c|c|c|c|c|c|c|c|c|c|c|}
\hline \multirow[b]{3}{*}{ Lesion } & \multicolumn{12}{|c|}{ Data set } \\
\hline & \multicolumn{3}{|c|}{1} & \multicolumn{3}{|c|}{2} & \multicolumn{3}{|c|}{3} & \multicolumn{3}{|c|}{ All } \\
\hline & RL & LF & BL & RL & LL & BL & RL & LL & BL & RL & LL & BL \\
\hline MYC & 52 & 33 & 64 & 148 & 156 & 192 & 201 & 196 & 37 & 401 & 385 & 493 \\
\hline CPL & 378 & 350 & 534 & 145 & 130 & 208 & 186 & 168 & 243 & 709 & 648 & 985 \\
\hline INS & 163 & 96 & 187 & 74 & 63 & 107 & 114 & 92 & 150 & 351 & 251 & 444 \\
\hline AP & 5 & 3 & 7 & 2 & 2 & 4 & 1 & 1 & 1 & 8 & 6 & 12 \\
\hline $\mathrm{CCB}$ & 2 & 1 & 2 & 13 & 8 & 19 & 18 & 17 & 29 & 33 & 26 & 50 \\
\hline CPN & 9 & 6 & 12 & 8 & 12 & 18 & 23 & 19 & 37 & 40 & 37 & 67 \\
\hline $\mathrm{N}$ & 1767 & 1767 & 1767 & 304 & 304 & 304 & 301 & 301 & 301 & 2372 & 2372 & 2372 \\
\hline
\end{tabular}

1-3: The 3 independent data sets. Set 1 constitute sows and gilts. Sets 2 and 3 are fatteners from 2 farrow-to-finish conventional herds.

MYC: (Uncomplicated) catarrhal bronchopneumonia (mycoplasma-like pneumonia). CPL: Chronic pleuritis. INS: Interlobular scar retractions. AP: Acute pleuropneumonia. CCB: Complicated catarrhal bronchopneumonia. CPN: Chronic pleuropneumonia.

RL, LL, BL: Right lung, left lung and both lungs (the plucks).

$\mathrm{N}$ : The number of lungs examined.

$\mathrm{p}=0.001$, respectively). For both lesions this was due to a larger right minus left lung difference in Set 1 compared to Sets 2 and 3. A correlation analysis on the combined data, analyzing the relative difference in lung score compared to the score of the plucks, indicated only weak associations (the highest correlation coefficient was 0.14 , for the case of catarrhal pneumonia). Thus it follows that when the relative difference remains fairly stable by different levels of lung score, the numerical difference between the score of right and left

Table 2. Over-all results of the study. The pathological score by data set and pathological entity, restricted to lungs in which lesions were detected in the right or left lung, or in both lungs (see Table 1 for legends).

\begin{tabular}{|c|c|c|c|c|c|c|c|c|c|c|c|c|}
\hline \multirow[b]{3}{*}{ Lesion } & \multicolumn{12}{|c|}{ Data set } \\
\hline & \multicolumn{3}{|c|}{1} & \multicolumn{3}{|c|}{2} & \multicolumn{3}{|c|}{3} & \multicolumn{3}{|c|}{ All } \\
\hline & RL & LF & $\mathrm{BL}$ & $\mathrm{RL}$ & LL & BL & RL & LL & BL & RL & LL & BL \\
\hline MYC & 2.42 & 1.14 & 3.56 & 3.85 & 2.37 & 6.22 & 6.44 & 2.89 & 7.32 & 3.95 & 2.46 & 6.40 \\
\hline CPL & 8.78 & 6.30 & 15.07 & 4.80 & 4.24 & 9.04 & 5.58 & 4.53 & 10.12 & 7.15 & 5.4 & 12.58 \\
\hline INS & 0,92 & 0,51 & 1.43 & 3.75 & 3.50 & 7.25 & 0.94 & 0.65 & 1.59 & 0.85 & 0.55 & 1.40 \\
\hline AP & 4.86 & 1.86 & 6.71 & 0.62 & 0.47 & 1.09 & 2.00 & 2.00 & 4.00 & 4.25 & 2.42 & 6.67 \\
\hline CCB & 5.00 & 2.00 & 7.00 & 2.79 & 1.05 & 3.84 & 3.76 & 3.24 & 7.00 & 3.44 & 2.36 & 5.80 \\
\hline CPN & 3.25 & 1.33 & 4.58 & 0.61 & 1.11 & 1.72 & 0.70 & 0.54 & 1.34 & 1.13 & 0.84 & 1.97 \\
\hline
\end{tabular}

MYC, AP, CCB, CPPN: The weight of affected tissue in percent of the total weight of both lungs.

CPL: The area of affected lung surface in percent of the total doso-lateral surface area of borh lungs.

INS: A score from $0-3$ by 0.5 was assigned to each of the lungs. The result for both lungs was estimated as the sum of the 2 scores. 


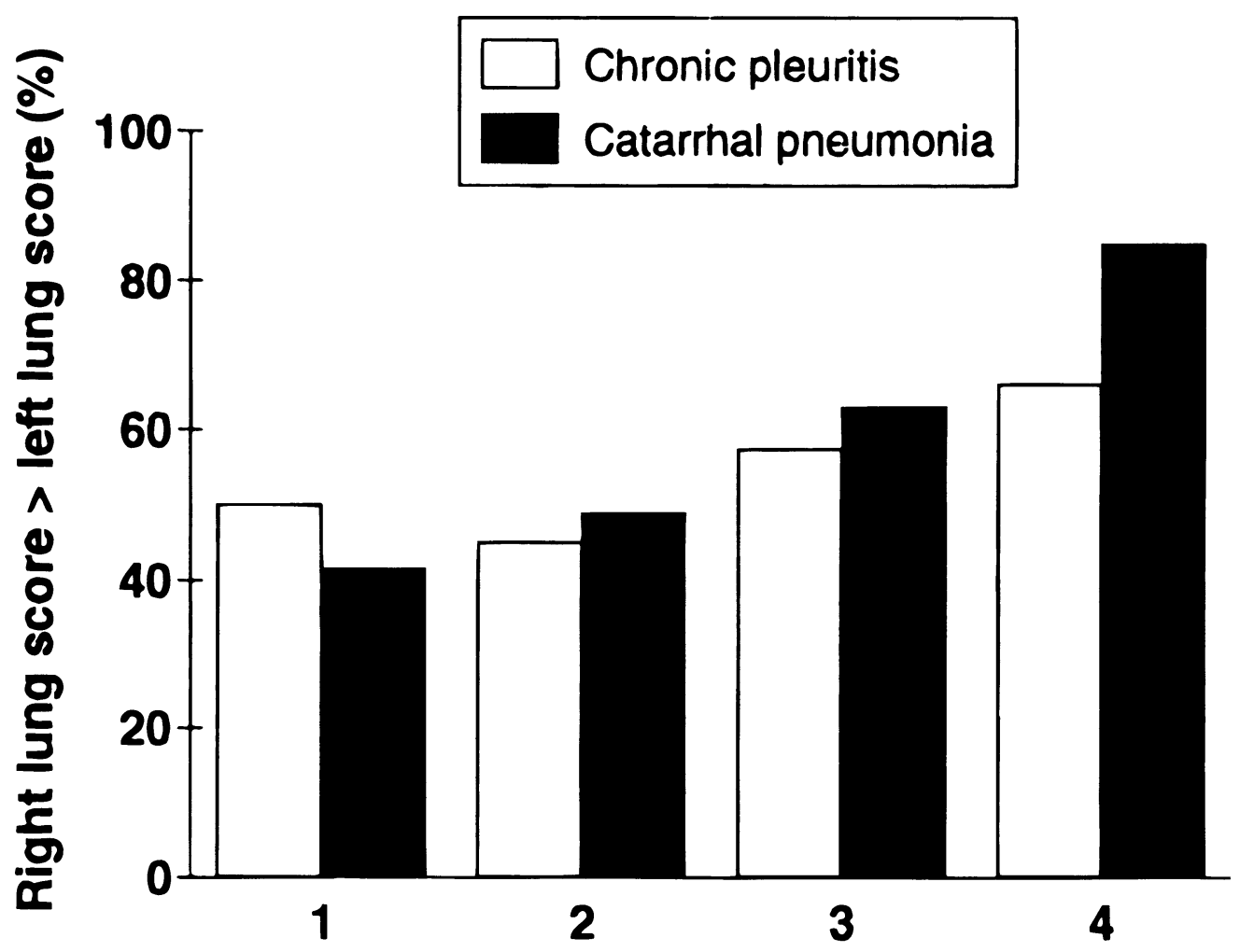

\section{Quartile of lesion score}

Figure 2. The percentage of the plucks in which the right lung score is larger than the left lung score by increasing (right plus left) lung score quartile. (Score quartiles corresponded to the following values: chronic pleuritis: $1: 1-4 \%, 2: 5-8 \%, 3: 9-14 \%, 4: 15-100 \%$. Catarrhal pneumonia: $1: 1-2 \%, 2: 3-4 \%, 3: 5-8 \%, 4: 9-57 \%$ ).

lung increases by increasing severeness of the lesion.

This fact is illustrated in Fig. 2 for the case of catarrhal pneumonia and chronic pleuritis. The figure illustrates the percentage of plucks in which the right lung score is larger than the left lung score by increasing (combined) lung score quartile. For both lesions there were a statistically significant increasing trend ( $\mathrm{p}<0.001$ in both cases).

Table 5 gives similar results as Table 4, how- ever restricted to plucks in which lesions occurred in both lungs, and to the most common of the lesions found. The analysis of variance in this case revealed a statistical significant difference between the data sets for chronic pleuritis $(\mathrm{p}=0.003)$.

The minimum sample size of right lungs to detect at least 1 pig with catarrhal pneumonia or chronic pleuritis (with $95 \%$ certainty) is listed in Table 6. 
Table 3. Relative sensitivities of right and left lung findings compared to the combined result of both lungs (see Table 1 for legends).

\begin{tabular}{|c|c|c|c|c|c|c|c|c|c|c|}
\hline \multirow[b]{3}{*}{ Lesion } & \multicolumn{10}{|c|}{ Data set } \\
\hline & \multicolumn{2}{|c|}{1} & \multicolumn{2}{|c|}{2} & \multicolumn{2}{|c|}{3} & \multirow[b]{2}{*}{$p^{1)}$} & \multicolumn{2}{|c|}{ All } & \\
\hline & RL & LF & RL & LL & RL & LL & & RL & LL & $\mathrm{p}^{2)}$ \\
\hline MYC & 81.2 & 51.5 & 77.1 & 81.2 & 84.1 & 83.7 & 0.124 & 81.3 & 78.1 & 0.288 \\
\hline CPL & 70.8 & 65.5 & 69.7 & 62.5 & 76.5 & 69.1 & 0.181 & 72.0 & 65.8 & 0.015 \\
\hline INS & 87.2 & 51.3 & 69.2 & 58.9 & 76.0 & 61.3 & 0.001 & 79.0 & 56.5 & $<10^{-3}$ \\
\hline AP & 71.4 & 42.9 & 50.0 & 50.0 & 100.0 & 100.0 & - & 66.7 & 50.0 & 0.752 \\
\hline $\mathrm{CCB}$ & 100.0 & 50.0 & 68.4 & 42.1 & 62.1 & 58.6 & 0.655 & 66.0 & 52.0 & 0.348 \\
\hline CPN & 75.0 & 50.0 & 44.4 & 66.7 & 62.2 & 51.3 & 0.223 & 59.7 & 55.2 & 0.791 \\
\hline
\end{tabular}

1) $\mathrm{p}$ value for $\mathrm{Chi}^{2}$ test for difference in $\mathrm{RL}$ results between data sets.

2) $\mathrm{p}$ value for $\mathrm{McNemars} \mathrm{Chi}^{2}$ test for the difference in $\mathrm{RL}$ and $\mathrm{LL}$ results on the aggregared data.

Table 4. The relative difference in lung scores between the right and the left lung in percent (right lung score minus left lund score in percent of the combined lung scores of both lungs). Restricted to plucks in which lesions were detected in left or right lung, or in both lungs (see Table 1 for legends).

\begin{tabular}{|c|c|c|c|c|c|c|c|c|}
\hline \multirow[b]{3}{*}{ Lesion } & \multicolumn{8}{|c|}{ Data set } \\
\hline & \multicolumn{2}{|c|}{1} & \multicolumn{2}{|c|}{2} & \multicolumn{2}{|c|}{3} & \multicolumn{2}{|c|}{ All } \\
\hline & Dif. & $\mathrm{p}^{1}$ & Dif. & $\mathrm{p}$ & Dif. & $\mathrm{p}$ & Dif. & $\mathrm{p}$ \\
\hline MYC & 35.0 & $<10^{-3}$ & 6.1 & 0.229 & 12.6 & 0.002 & 13.0 & $<10^{-3}$ \\
\hline CPL & 10.3 & 0.004 & 6.6 & 0.266 & 8.4 & 0.094 & 9.0 & $<10^{-3}$ \\
\hline INS & 37.2 & $<10^{-3}$ & 11.6 & 0.163 & 17.4 & 0.008 & 24.3 & $<10^{-3}$ \\
\hline AP & 34.4 & 0.373 & 0.0 & 1.000 & 0.0 & - & 20.0 & 0.476 \\
\hline $\mathrm{CCB}$ & 60.0 & 0.374 & 26.9 & 0.224 & 11.5 & 0.508 & 19.3 & 0.140 \\
\hline CPN & 69.8 & 0.267 & -22.2 & 0.331 & 10.8 & 0.487 & 5.2 & 0.647 \\
\hline
\end{tabular}

1) p-values corresponding to a t-test for the hypothesis of the relative difference being equal to zero.

Table 5. The relative difference in lung scores between the right and the left lung in percent (right lung score minus left lung score in percent of the combined lung scores of both lungs). Restricted to plucks in which lesions occured in both lungs, and to the most commonly occurring lesions (see Table 1 for legends).

\begin{tabular}{|c|c|c|c|c|c|c|c|c|c|c|c|c|}
\hline \multirow[b]{3}{*}{ Lesion } & \multicolumn{12}{|c|}{ Data set } \\
\hline & \multicolumn{3}{|c|}{1} & \multicolumn{3}{|c|}{2} & \multicolumn{3}{|c|}{3} & \multicolumn{3}{|c|}{ All } \\
\hline & $\mathrm{N}$ & Dif. & $\mathrm{p}^{1}$ & $\mathrm{~N}$ & Dif. & $\mathrm{p}$ & $\mathrm{N}$ & Dif. & $\mathrm{p}$ & $\mathrm{N}$ & Dif. & $\mathrm{p}$ \\
\hline MYC & 21 & 16.1 & 0.008 & 112 & 17.6 & $<10^{-3}$ & 160 & 15.5 & $<10^{-3}$ & 293 & 16.4 & $<10^{-3}$ \\
\hline CPL & 194 & 13.9 & $<10^{-3}$ & 67 & -1.9 & 0.693 & 111 & 2.2 & 0.561 & 372 & 7.6 & $<10^{-3}$ \\
\hline INS & 72 & 3.8 & 0.113 & 30 & 4.8 & 0.300 & 56 & 7.2 & 0.033 & 158 & 5.2 & 0.004 \\
\hline
\end{tabular}

1) p-values corresponding to a t-test for the hypothesis of the relative difference being equal to zero. 
Table 6. Sample size to detect at least 1 affected right lung by prevalence (p) in percent, 2 levels of herd size and disease category $(95 \%$ confidence level. See Table 1 for legends).

\begin{tabular}{crrrrr}
\hline$p$ & \multicolumn{2}{c}{500 pigs } & & \multicolumn{2}{c}{200 pigs } \\
\cline { 2 - 3 } \cline { 6 - 6 }$(\%)$ & MYC & CPL & & MYC & CPL \\
\hline 2 & 156 & 174 & & 126 & 155 \\
5 & 69 & 76 & & 62 & 69 \\
10 & 35 & 39 & & 62 & 38 \\
20 & 17 & 19 & & 17 & 19 \\
\hline
\end{tabular}

\section{Discussion}

The 3 independent data sets yields in our view a sufficient background for a methodological evaluation of the value of examining the right lungs alone. In the sow material, the low prevalence of catarrhal pneumonia $(3.6 \%)$ was as expected, due to the resolution of this type of pneumonia by time. However, the relatively high prevalence of interlobular scar retractions (at $10.6 \%$ ) probably reflects that the sows examined have in their past suffered from this type of pneumonia (Christensen \& Mousing 1992). The 2 materials from conventional farrow-to-finish herds revealed very high prevalences for catarrhal pneumonia and chronic pleuritis. The 2 herds were both selected for study due to a high prevalence of lesions recorded by routine meat inspection, and both herds were infected with commonly occurring respiratory and other infections. Thus, infections in both herds with the following agents were all confirmed serologically or microbiologically: Actinobacillus pleuropneumoniae (serotypes 1, 2 and 6), Mycoplasma hyopneumoniae, Pasteurella multocida, Haemophilus parasuis and Influenza suis (VraaAndersen 1991, Paisley 1991). Accordingly, the relative sensitivities from data sets 2 and 3 are based on pathology associated with the most commonly occurring infections in modern swine production worldwide (Christensen \& Mousing 1992).
A right lung test is characterized by a relative sensitivity below $100 \%$ and a specificity of (in practice) $100 \%$. In this respect, the right lung test is parallel to many microbiological surveys. Given á priori knowledge of the test sensitivity, an estimate of the true population prevalence can be easily obtained by dividing the proportion of test positive animals with the test sensitivity. This has not been fully appreciated in previous surveys, but current microbiological studies have now emphasized this fact (Bager \& Petersen 1992).

For all types of lesions, the right lung relative sensitivities were higher than the corresponding left lung results (Table 3 ). This difference was statistically different for chronic pleuritis and interlobular scar retractions. Also, the right lung sensitivities did not differ markedly between the 3 data sets. The only exception was found for interlobular scar retractions, where the right lung sensitivity in sows was above the sensitivities in the 2 slaughterpig materials (which did not differ).

In conclusion, a qualitative (i.e. present/not present) evaluation of the right lung was consistently the better choice if just 1 of the lungs were to be evaluated, with relatively high sensitivities that were consistent across different data sets.

If scoring the severeness of the lesions is the aim of the investigation, similar conclusions can be drawn (Tables 4 and 5). In general, the right lung score is relatively larger than the left lung score, and this difference was found statistically significant for catarrhal pneumonia, chronic pleuritis and interlobular scar retractions. However, for catarrhal pneumonia and interlobular scar retractions, the magnitude of this difference was not similar in the 3 data sets.

As seen in Fig. 2, the right lung score was more often larger than the left lung score in severely affected lungs. 
It was further demonstrated, that the relative difference in lung scores in general could not be explained by the differences in right and left lung sensitivities (Table 5). Even when comparing lung scores for plucks in which lesions occurred in both lungs, the score in the right lung was larger then the corresponding left lung score. However, this result was not consistent between the 3 data sets for the case of chronic pleuritis.

In consequence, an evaluation of right lung pathology appears as a useful alternative to an examination of the entire plucks, when the purpose of the survey is to demonstrate the presence or absence of lesions, or when scoring the severeness of lesions is the objective.

\section{References}

Armitage P, Berry G: Statistical methods in medical research. Blackwell Scientific Publications, 1987, pp. 104-112, 120-132, 186-194.

Bager F, Petersen J: Interpretation of microbiological tests for latent salmonella infections in pigs. Proceedings, Int. Pig. Vet. Soc., Den Haag, 1992. In Press.

Christensen G: USK Udvidet sygdomskontrol. Håndbog. (Extended disease control. Handbook). The Federation of Danish Pig Producers and Slaughterhouses, Veterinary Division, 1991. Not Published.

Christensen G: Unpublished results, 1990.

Christensen $G$, Mousing J: Respiratory System. In: Leman AD, Straw BE, Mengeling WL, D'Allaire S, Taylor DJ (eds): Diseases of swine, editors: $7^{\text {th }}$ Edition, Iowa State University Press, 1992, pp. 138-162.

Heilmann P, Müller G, Finsterbrusch L: Lobäre Deposition radioaktiv markierter Pasteurella multocida Aerosole in den Lungen von Ferkeln und Kälbern (Lobular exposure with radioactive marked Parturrella Multocida aerosol in the lungs of pigs and calves). Arch. Exp. Vet. Med., $1988,42,490-501$

Levy PS, Lemeshow S: Sampling for health professionals. Lifetime Learning Publications, USA, 1980. p. 47.
Martin SW, Meek AH, Willeberg P: Veterinary epidemiology. Principles and methods. Iowa State University Press, 1987, pp. 37, $62-73$.

Morrison RB, Hilley, $H D$, Leman $A D$ : Comparison of methods for assessing the prevalence of pneumonia in market weight swine. Can. vet. J., 1985, 26, 381-384

Paisley LG: A prospective study of the economic impact of chronic pleuritis and other respiratory diseases in two conventional danish swine herds. $\mathrm{Ph}$.D. Thesis, The Royal Veterinary and Agricultural University, Copenhagen, Denmark, 1991.

SAS Institute Inc.: SAS/STAT TM User's Guide, Release 6.03 Edition. Cary, NC: SAS Institute Inc., 1988.

Vraa-Andersen L: Analysis of risk factors related to infection with Actinobacillus pleuropneumonia and Mycoplasma hyopneumoniae in swine. Proc. 6th Int. Symp. Vet. Epi. Econ., Ottawa, Canada 12-16 August 1991, pp. 419-421.

\section{Sammendrag}

Patologiske fund $i$ højre og venstre lunge hos svinet: Evaluering af en alternativ metode til scoring af lungelcesioner baseret på unders $\emptyset$ gelse af højre lunge. Pluks fra 2372 søer, gylte og slagtesvin (fra 3 uafhængige datamaterialer) blev unders $\emptyset$ gt for forekomst og udbredelse af 6 forskellige patologiske tilstande. Resultaterne blev opgjort for hver af de to lunger separat, og sammenlignet med resultatet for begge lunger kombineret. Såvel kvalitativt (hvor man sammenlignede relativ sensitivitet) og kvantitativt (hvor man sammenlignede lungescoren) var resultatet for højre lunge sammenlignelige imellem de 3 datamaterialer, og mere optimalt end de tilsvarende resultater for venstre lunge. Den relative sensitivitet for påvisning af henholdsvis kataralsk pneumoni og kronisk pleuritis var $81,3 \%$ og $72,0 \%$ (baseret på det samlede materiale). Den procentvise forskel mellem højre og venstre lunges score for de to sygdomstilstande var $13,0 \%$ og $9,0 \%$ (bestemt på lunger hvor der kunne påvises patologiske forandringer). Den nødvendige prøvestørrelse af højre lunger fra en besætning til påvisning af mindst én lunge med kataralsk pneumoni eller kronisk pleuritis er beregnet ved forskellige besætningsprævalenser. Endelig anvises en metode til beregning af konfidensinterval for prævalensen bestemt ved undersøgelse af højre lunger.

(Received September 21, 1992; accepted January 6, 1993).

Reprints may be requested from: J. Mousing, Federation of Danish Pig Producers and Slaughterhouses, Veterinary Division, Axeltorv 3, DK-1609 Copenhagen C, Denmark. 